\title{
As(III) adsorption on Fe-Mn binary oxides: are manganese and iron oxides synergistic or 1 antagonistic for arsenic removal?
}

by Zhen, Q., Hou, J., Hartley, W., Ren, L., Wang, M., Tu, S. and Tan, W.

Copyright, publisher and additional Information: This is the author accepted manuscript. The final published version (version of record) is available online via Elsevier.

This version is made available under the CC-BY-ND-NC licence:

https://creativecommons.org/licenses/by-nc-nd/4.0/legalcode

Please refer to any applicable terms of use of the publisher

DOI: https://doi.org/10.1016/j.cej.2020.124470

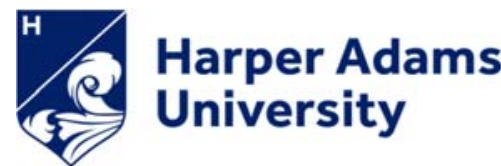

Zhen, Q., Hou, J., Hartley, W., Ren, L., Wang, M., Tu, S. and Tan, W. 2020. As(III) adsorption on Fe-Mn binary oxides: are manganese and iron oxides synergistic or 1 antagonistic for arsenic removal? Chemical Engineering Journal.

16 February 2020 

antagonistic for arsenic removal?

Qian Zheng, ${ }^{1}$ Jingtao Hou,,${ }^{1, *}$ William Hartley, ${ }^{2}$ Lu Ren ${ }^{3}$, Mingxia Wang, ${ }^{1}$ Shuxin Tu, ${ }^{1, *}$ Wenfeng $\operatorname{Tan}^{1}$

${ }^{1}$ College of Resources and Environment, Huazhong Agricultural University, Wuhan 430070, China.

${ }^{2}$ Crop and Environment Sciences Department, Harper Adams University, Newport, Shropshire, TF10 8NB, United Kingdom.

${ }^{3}$ School of Civil Engineering, Suzhou University of Science and Technology, Suzhou 215009, China

ABSTRACT. Fe-Mn binary oxides are ubiquitous in the natural environment and have attracted increasing interest due to their high removal capacity for As(III), as well as their important role in the natural cycling of arsenic. Although numerous studies have characterized the respective roles of Fe and Mn oxides in As(III) removal, the relationship between different Fe-Mn binary oxides for As(III) removal has not been fully explored. In this study, three Fe-Mn binary oxides containing either ferrihydrite, hematite or goethite, were used to evaluate their adsorption capacities for As(III) in comparison with their corresponding single Fe and Mn oxide forms. We utilized spectroscopic techniques of in situ flow ATR-FTIR and XPS combined with a Donnan reactor, where Fe and Mn oxides were isolated by a semipermeable membrane through which arsenic could pass, to investigate the dynamics and speciation transformation of As(III) within mixed Fe and Mn oxides systems. The result showed that the synergistic effect, as well as antagonistic effects, between Fe and Mn oxides, was present in Fe-Mn binary oxides for As(III) removal. An obvious increase in As(III) removal with hematite, containing Fe-Mn binary oxides, and a decrease in ferrihydrite, containing Fe-Mn binary oxides, was attributed to As(III) oxidation mediated by Mn oxides as well as the difference in arsenic adsorption affinity in Fe oxides, evidenced by ATR-FTI R and XPS analyses. The findings of this work provide a new understanding of the fate of arsenic within mixed systems, which is very important for targeted application of Fe-Mn binary oxides 
24

in treating real arsenic contaminated groundwater.

\section{INTRODUCTION}

Arsenic (As) is a common metal(loid) element that has gained much concern due to its high toxicity and carcinogenicity [1, 2]. In order to reduce the associated health risks, a guideline limit of $10 \mu \mathrm{g} \mathrm{L}^{-1} \mathrm{As}$ in drinking water was set by the World Health Organization (WHO) [3]. In the natural environment, As is mainly present as inorganic forms, existing in two predominant species, arsenite [As(III)] and arsenate $[\mathrm{As}(\mathrm{V})][1]$. Arsenite is the major As species in reduced environments, possessing greater toxicity, but having a weaker affinity to metal oxides compared to $\mathrm{As}(\mathrm{V})$. Arsenate mainly exists in well-oxygenated environments [1, 4]. The strategy for oxidation of As(III) coupled with sorption of the formed $\mathrm{As}(\mathrm{V})$, using metal binary oxides as adsorbents, has been intensively investigated for treating As contaminated groundwater [2].

The reported binary oxides include Ce-Mn [5-7], Zr-Mn [8, 9], Ti-Mn [10-12], Fe-Mn [13-16] and AlMn $[17,18]$ etc. Among the series of binary oxides, Fe-Mn binary oxide, which is inexpensive and environmentally benign, has attracted much interest as a promising adsorbent for As removal, especially for As(III). Arsenite removal on Fe-Mn binary oxides reportedly follows an oxidation/adsorption mechanism, in which $\mathrm{As}(\mathrm{III})$ is oxidized to $\mathrm{As}(\mathrm{V})$ by manganese oxides, and the formed $\operatorname{As}(\mathrm{V})$ subsequently being adsorbed by the iron oxides [19-22]. Therefore, the existence of synergistic effects between manganese oxides (oxidants) and iron oxides (adsorbents) in Fe-Mn binary oxides, for As(III) removal, is widely accepted. However, several studies have reported that some iron (hydr-)oxides demonstrated lower adsorption capacities toward As(V) than As(III) [23-25]. For example, Zhang et al evaluated $\operatorname{As}(\mathrm{III})$ and $\operatorname{As}(\mathrm{V})$ adsorption capacities on amorphous ferrihydrite, and revealed that adsorption performance of As(III) on amorphous ferrihydrite was 2.15 times greater than that of $\mathrm{As}(\mathrm{V})$ 
[24]. Wen et al also observed that iron hydroxide colloids showed As(III) adsorption capacity to be higher than that of $\operatorname{As}(\mathrm{V})$ [25]. Therefore, oxidation of $\mathrm{As}(\mathrm{III})$ by manganese oxides may be detrimental for As(III) removal. In principle, the type and content of iron (e.g., ferrihydrite, goethite, and hematite) and manganese oxides in both naturally occurring and synthesized Fe-Mn binary oxides are rather different, which depend on the natural environment as well as their preparation conditions. Although the respective roles of Fe and Mn oxides in As(III) removal have been characterized in previous studies [19, 22, 24, 26-28], the working relationship between Fe and Mn oxides with different Fe-Mn binary oxides is not fully understood. It is still unclear whether antagonistic and/or synergistic effects occur in Fe-Mn binary oxides during As removal. Elucidating these effects is very important for targeted application of Fe-Mn binary oxides in treating real As contaminated groundwater.

In this study, three Fe-Mn binary oxides containing either ferrihydrite, goethite or hematite, were synthesized using a superficial co-precipitation reaction. Arsenite adsorption capacities of the different Fe-Mn binary oxides were tested for comparison with their corresponding single $\mathrm{Fe}$ and $\mathrm{Mn}$ oxides. To illustrate the possible working relationships between $\mathrm{Fe}$ and $\mathrm{Mn}$ in the different binary oxides, we examined As(III) dynamics using a Donnan reactor composed of two reaction cells separated by a semipermeable membrane, where Fe and Mn oxides were placed in two chambers, respectively.

\section{MATERIALS AND METHODS}

Materials. $\mathrm{As}_{2} \mathrm{O}_{3}$ and $\mathrm{Na}_{3} \mathrm{AsO}_{4} \cdot 12 \mathrm{H}_{2} \mathrm{O}$ were used to prepare $\mathrm{As}(\mathrm{III})$ and $\mathrm{As}(\mathrm{V})$ stock solutions, respectively. The $\mathrm{As}(\mathrm{III})$ and $\mathrm{As}(\mathrm{V})$ working solutions were prepared by diluting the corresponding stock solutions using deionized water. Manganese oxide samples used in this study were purchased from Sinopharm group chemical reagent co., LTD, China. All reagents were of analytical grade. A 
polycarbonate semi-permeable membrane with a diameter of $100 \mathrm{~mm}$ was used in the Donnan reactor (Kenker Co., USA).

Sample Preparation. Ferrihydrite-containing Fe-Mn binary oxides were synthesized according to Zhang et al [29], using co-precipitation but with the addition of $\mathrm{MnCl}_{2}$. Typically, $\mathrm{Fe}\left(\mathrm{NO}_{3}\right)_{3} \cdot 9 \mathrm{H}_{2} \mathrm{O}(0.1$ M) $(500 \mathrm{~mL})$ and $\mathrm{MnCl}_{2}(0.5 \mathrm{M})(60 \mathrm{~mL})$ were thoroughly mixed together with $\mathrm{NaOH}(1 \mathrm{M})(330 \mathrm{~mL})$ using a magnetic stirrer until the solution $\mathrm{pH}$ reached $7 \sim 8$. After stirring for $2 \mathrm{~h}$, the precipitates were washed several times with deionized water until conductivity was lower than $20 \mathrm{mS} \mathrm{cm}^{-1}$. The samples were then freeze-dried and subsequently stored at $4{ }^{\circ} \mathrm{C}$ until required.

Goethite-containing Fe-Mn binary oxides were prepared using a similar method [30]. Typically, $\mathrm{Fe}\left(\mathrm{NO}_{3}\right)_{3} \cdot 9 \mathrm{H}_{2} \mathrm{O}(1 \mathrm{M})(100 \mathrm{~mL})$ and $\mathrm{MnCl}_{2}(0.5 \mathrm{M})(60 \mathrm{ml})$ were thoroughly mixed. $\mathrm{NaOH}(5 \mathrm{M})(180$ $\mathrm{mL}$ ) was then added and constantly stirred using a magnetic stirring. The suspension was diluted to a volume of $2 \mathrm{~L}$ with distilled water, sealed with plastic wrap, and then placed in an oven at $70^{\circ} \mathrm{C}$ for 60 h. The precipitate was washed with deionized water, dried at $60^{\circ} \mathrm{C}$ for 1 day, and subsequently stored at $4{ }^{\circ} \mathrm{C}$ until required.

Hematite-containing Fe-Mn binary oxides were prepared according to the method of Connell and Schwertamnn, except for the addition of $\mathrm{MnCl}_{2}$ [31]. Typically, $\mathrm{Fe}\left(\mathrm{NO}_{3}\right)_{3} \cdot 9 \mathrm{H}_{2} \mathrm{O}(40 \mathrm{~g})$ was added to 500 $\mathrm{mL}$ of $90^{\circ} \mathrm{C}$ deionized water in a $1000 \mathrm{~mL}$ beaker with constant magnetic stirring. $\mathrm{MnCl}_{2}(0.5 \mathrm{M}),(60 \mathrm{~mL})$, $\mathrm{KOH}(1 \mathrm{M})(300 \mathrm{~mL})$ and $\mathrm{NaHCO}_{3}(1 \mathrm{M})(50 \mathrm{~mL})$ were preheated to $90{ }^{\circ} \mathrm{C}$ and subsequently added to the above suspension. The beaker was sealed with plastic wrap and transferred to a $90^{\circ} \mathrm{C}$ oven . After 48 h, the precipitate was washed with deionized water several times, dried at $60{ }^{\circ} \mathrm{C}$, and stored at $4{ }^{\circ} \mathrm{C}$ until required. 
corresponding binary oxides but with the exception of no $\mathrm{MnCl}_{2}$ addition.

Sample Characterization. X-ray diffraction (XRD) patterns for the different iron oxides and manganese oxides were tested on a Bruker D8 ADVANCE X-ray diffractometer using Ni-filtered $\mathrm{Cu}$ Ka radiation. Scanning electronic microscopy (SEM) images and energy dispersion spectrum (EDS) data were obtained using a QUANTA FEG 450 electron microscope. Nitrogen adsorption-desorption isotherms were obtained using a Micromeritics ASAP 2000 surface area analyzer. The spectra generated by X-ray photoelectron spectrometry (XPS) spectra of the samples before and after reaction with As(III) in Donnan experiments were collected using a VG Multilab 2000 X-ray photoelectron spectrometer with Mg Ka radiation. Some selected samples were freeze-dried before being characterized by XPS.

As(III) Oxidation Experiment. As(III) oxidation on manganese oxide was performed on a thermostatic shaker with a velocity of $200 \mathrm{rpm}$ at $25^{\circ} \mathrm{C}$. The initial As(III) solution was $1.33 \mu \mathrm{M}$ with an ionic strength of $0.1 \mathrm{M} \mathrm{NaNO}_{3}$ and a $\mathrm{pH}$ of $7.0 \pm 0.1$ adjusted by adding appropriate $\mathrm{HCl}$ or $\mathrm{HNO}_{3}$. To start, $0.01 \mathrm{~g}$ of manganese oxide were rapidly added into $1.33 \mu \mathrm{M}$ of As(III) working solution in a $150 \mathrm{~mL}$ Erlenmeyer flask. At set specific time intervals, the suspensions were filtered through a $0.22 \mu \mathrm{m}$ membrane filter. The concentration of total As and As(III) species were tested on an atomic fluorescence spectrometer (AFS-9700) according to the detection method reported by Hong et al [32]. The As(V) concentration in solution was obtained by subtracting the As(III) concentration from the total As concentration.

Arsenic Adsorption Experiment. The arsenic adsorption performance of Fe (hydr-)oxide, Mn oxide, the Fe-Mn binary oxides, and mixed Fe and Mn oxides, were investigated using adsorption isotherms at $\mathrm{pH} 7.0$ in a dark environment. All adsorption experiments were performed on a thermostatic shaker with a velocity of $200 \mathrm{rpm}$ at $25^{\circ} \mathrm{C}$ for $24 \mathrm{~h}$. The ion strength in all bath experiments was adjusted to $0.1 \mathrm{M}$ using $\mathrm{NaNO}_{3}$. Typically, $0.01 \mathrm{~g}$ of Fe oxide, Mn oxide, or Fe-Mn binary oxide were added into $100 \mathrm{~mL}$ 
of arsenic solution with a series of concentrations ranging from 0.13 to $133.3 \mu \mathrm{M}$ in a $150 \mathrm{~mL}$ Erlenmeyer flask. During the adsorption experiment, solution $\mathrm{pH}$ was adjusted every $6 \mathrm{~h}$ using $\mathrm{HCl}$ and $\mathrm{NaOH}$ to $7.0 \pm 0.1$. After $24 \mathrm{~h}$, the suspensions were withdrawn and filtered through a $0.22 \mu \mathrm{m}$ membrane filter. Arsenic adsorption performance of the mixed Fe and Mn oxides was also tested using the same treatment as that of single Fe oxide except for the addition of $0.01 \mathrm{~g}$ of Mn oxide. The amount of adsorbed As on iron oxide surfaces was obtained by subtracting the residual As concentration from the initial As concentration divided by the weight of Fe oxide adsorbent. All batch adsorption experiments were carried out in triplicate.

Donnan Experiment. The Donnan reactor used in this study was composed of two reaction cells separated by a semi-permeable membrane (Figure 1) [30]. The reaction cells were constructed using acrylic pipes. A $0.1 \mu \mathrm{m}$ polycarbonate filter was used as the semi-permeable membrane. Before the experiment, the Donnan reactor was carefully tested for leakages by adding water into the two reaction cells. To start, $0.2 \mathrm{~g}$ of Fe oxide and $0.2 \mathrm{~g}$ of Mn oxide were placed into two reaction cells, respectively (Figure 1). To determine the relationship between Fe and Mn oxides for As(III) removal, two experiments were designed. For the first experiment, only As(III) was added into the Fe oxide chamber (Figure S1A, see supporting information), and the second only As(III) was added into the Mn oxide chamber (Figure S1B). Considering that the two iron oxides have different adsorption capacities for As removal, evidenced from the adsorption experiment, the initial As(III) concentration in ferrihydrite-Mn oxide and hematite-Mn oxide systems was set as 133.3 and $26.7 \mu \mathrm{M}$, respectively. The initial $\mathrm{pH}$ in all reactions was set to $7.0 \pm 0.1$. Following the reaction, $\mathrm{pH}$ was monitored and adjusted using $\mathrm{HCl}$ and $\mathrm{NaOH}$. The ionic strength in the two cells was adjusted to $0.1 \mathrm{M}$ using $\mathrm{NaNO}_{3}$. The aqueous As concentration (c) at a given time in the Donnan reactor was calculated according to the following formula. 
Where $c_{1}$ and $c_{2}$ represent the As concentration in Fe and Mn oxide chambers, respectively $\left(\mu \mathrm{mol} \mathrm{L} \mathrm{L}^{-1}\right)$.

\section{In situ Flow Attenuated Total-reflectance Fourier Transform Infrared Spectroscopy (ATR-FTIR)}

139

Experiments. In-situ flow ATR-FTIR was used to measure the adsorption/oxidation of As(III) on single Fe oxides and mixed $\mathrm{Fe}$ and Mn oxides, thereby explaining the respective roles of $\mathrm{Fe}$ and $\mathrm{Mn}$ oxides in different Fe-Mn binary oxides for As(III) removal. Typically, $0.05 \mathrm{~g}$ of iron oxide was added to $1 \mathrm{~mL}$ of deionized water for ultrasonic dispersion for $\sim 5 \mathrm{~min}$. The obtained suspension was covered on $\mathrm{ZnSe}$ crystals and dried at room temperature for $12 \mathrm{~h}$. Before the experiment began, $0.1 \mathrm{M}$ of $\mathrm{NaNO}_{3}$ solution with $\mathrm{pH}$ of 7.0 was used as a background electrolyte, to pump through the iron oxide covered $\mathrm{ZnSe}$ crystals at a flow rate of $1.0 \mathrm{~mL} \mathrm{~min}^{-1}$, thereby balancing the functional groups on iron oxides. After 90 min, $1 \mathrm{mM}$ of $\mathrm{As}(\mathrm{III})$ solution ( $\mathrm{pH}=7.0$ ) was continuously pumped through the iron oxide covered $\mathrm{ZnSe}$

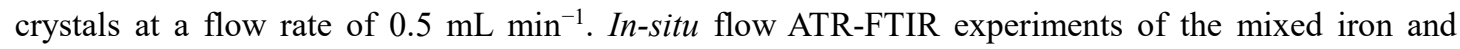
manganese oxides reacted with As(III) were performed using the same treatment as that of the iron oxide except for the addition of $0.05 \mathrm{~g}$ Mn oxide. As(III) adsorption/oxidation was monitored by a DTGS detector with an infrared spectrum acquisition. The scanning range, IR resolution, and scanning times were set to $4000 \sim 600 \mathrm{~cm}^{-1}, 4 \mathrm{~cm}^{-1}$, and 512, respectively. The OPUS software was employed for data processing. 


\section{RESULTS AND DISCUSSION}

158 Characterization of Fe (hydr-)oxides, Mn oxide and Fe-Mn binary oxides. The X-ray diffraction

159 (XRD) patterns of the Fe (hydr-)oxides, Mn oxide and Fe-Mn binary oxides are revealed in Figure S2.

160 XRD analysis revealed that Fe oxides used in this study were indexed to the pure structure of 2-line ferrihydrite [14], hematite [JCPDS 13-0534], and goethite [JCPDS 02-0282], respectively (Figure S2A).

162 Mn oxide was typical of the manganite phase [JCPDS 42-1316]. Fe oxide phases in different Fe-Mn binary oxides were ferrihydrite, hematite, and goethite, respectively (Figure S2B). No Mn oxide phase was observed in all $\mathrm{Fe}-\mathrm{Mn}$ binary oxides due to the low initial $\mathrm{MnCl}_{2} / \mathrm{Fe}\left(\mathrm{NO}_{3}\right)_{3}$ reactant molar ratio in all reaction systems. The EDS data revealed that both Fe and Mn elements coexisted (Table S1, see supporting information), suggesting Mn oxide was successfully incorporated into all Fe-Mn binary oxides. SEM images revealed that the surface of ferrihydrite-containing Fe-Mn binary oxides (denoted as $\mathrm{Fh}-\mathrm{MnO}_{x}$ ) was very rough, containing bumps and hollows, relative to that of hematite-containing Feincorporated into Goe- $\mathrm{MnO}_{x}$ samples (Figure S3B). The BET surface areas of the samples, determined which had been observed in previous work. The specific surface areas of Fh- $\mathrm{MnO}_{x}$, Goe- $\mathrm{MnO}_{x}$, and 
179 Arsenic adsorption in single Fe oxide and mixed Fe and Mn oxides. Figure 2 exhibits the adsorption 180 isotherm profiles of Fe oxides, Mn oxide, and mixed Fe and Mn oxides for As removal. The Langmuir and Freundlich models were used to describe the adsorption isotherms and the corresponding fitting

results are displayed in Table S3. We used a maximum adsorption amount calculated from the Langmuir model for comparing adsorption capacities. As shown in Figure 2 and Table S3, three iron oxides ferrihydrite, goethite, and hematite, which exist extensively in terrestrial environments, showed obvious differences in their adsorption capacities for both $\mathrm{As}(\mathrm{III})$ and $\mathrm{As}(\mathrm{V})[23,24,33]$. Ferrihydrite possessed the greatest adsorption capacity for both $\mathrm{As}(\mathrm{III})$ and $\mathrm{As}(\mathrm{V})$, followed by goethite and hematite. Interestingly, the three iron oxides exhibited different affinities for As(III) and As(V) species. For single hematite, its maximum As(III) adsorption capacity $\left(51.2 \mu \mathrm{mol} \mathrm{g} \mathrm{g}^{-1}\right)$ was lower than that of As(V) (65.3 $\mu \mathrm{mol} \mathrm{g}{ }^{-1}$ ) (Figure 2a). For goethite, its maximum As(III) adsorption capacity (112.8 $\left.\mu \mathrm{mol} \mathrm{g}^{-1}\right)$ was slightly greater that of $\mathrm{As}(\mathrm{V})\left(102.7 \mu \mathrm{mol} \mathrm{g} \mathrm{g}^{-1}\right)$ (Figure 2b). However, for ferrihydrite, the maximum As(III) adsorption capacity ( $871.5 \mu \mathrm{mol} \mathrm{g} \mathrm{g}^{-1}$ ) was much greater than that of $\mathrm{As}(\mathrm{V})\left(493.8 \mathrm{mg} \mathrm{g}^{-1}\right)$ (Figure 2c). Compared to iron oxides, manganese oxide possessed very low adsorption capacity for both As(III) and As(V) removal (Figure S4), but extremely high oxidation activity for As(III) (Figure S5), suggesting that manganese oxide mainly acts as an oxidant for oxidation of As(III) to As(V), rather than as an adsorbent [34-37]. Therefore, based on the above results, we speculated that the working relationships between Fe and Mn oxides in Fe-Mn binary oxides for As(III) removal, exist either synergistically, or antagonistically in some cases. However, this observation was not clear in previous work, and still needs further clarification. In order to confirm our assumption, As(III) adsorption capacities of the mixed Fe and Mn oxides was 
investigated for comparison with corresponding single Fe and Mn oxides (Figure 2). For mixed hematite and Mn oxides, As(III) adsorption capacity was $90.9 \mu \mathrm{mol} \mathrm{g}^{-1}$ (Figure 3d), which was clearly greater than those of single hematite $\left(51.2 \mu \mathrm{mol} \mathrm{g}^{-1}\right)$ and Mn oxides ( $\left.9.5 \mu \mathrm{mol} \mathrm{g}^{-1}\right)$, suggesting that the synergistic effect between hematite and Mn oxide was present in promoting As removal in this case. For the mixed goethite and Mn oxide, its As(III) adsorption capacity increased slightly to $116.3 \mu \mathrm{mol} \mathrm{g}{ }^{-1}$ relative to single goethite and $\mathrm{Mn}$ oxide, indicating that the additive effect between goethite and Mn oxide was observed with a slight enhancement in As(III) removal. Remarkably, for mixed ferrihydrite and Mn oxide, an obvious decrease in As(III) adsorption capacity $\left(694.4 \mu \mathrm{mol} \mathrm{g}^{-1}\right)$ was evident, relative to that of single

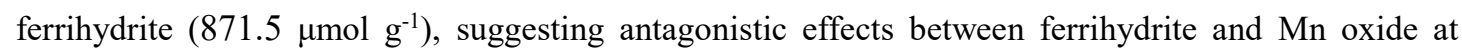
decreasing As(III) removal. This result demonstrated that the synergistic effect, as well as antagonistic effects, between Fe and Mn oxides, was present in Fe-Mn binary oxides for As(III) removal, which was in agreement with our assumption.

The question is therefore, why do antagonistic effects between Fe and Mn oxides occurr in mixed ferrihydrite and Mn oxide systems? There are two factors that affect As(III) removal. Firstly the change in As species mediated by Fe or Mn oxides, thus altering the adsorption affinity of As to iron oxides. Secondly, the Mn oxide adsorbed onto ferrihydrite surfaces, which occupies active sites for As(III) adsorption. We examined the $\mathrm{As}(\mathrm{V})$ adsorption capacity of the mixed ferrihydrite and Mn oxide for comparison with its corresponding single ferrihydrite (Table S2). The As(V) adsorption capacity of the mixed ferrihydrite and $\mathrm{Mn}$ oxide was $452.0 \mathrm{mg} \mathrm{g}^{-1}$, which was slightly lower than that of single ferrihydrite (493.8 $\left.\mathrm{mg} \mathrm{g}^{-1}\right)$. This result suggested that Mn oxide adsorbed onto iron oxide surfaces has a 'littering effect' on the active sites which could be used for As(III) adsorption, and the transformation of As species within the mixed Fe-Mn oxides system may play a vital role in As(III) removal. 

ferrihydrite $\left(\mathrm{Fh}-\mathrm{MnO}_{x}\right)$, goethite $\left(\mathrm{Goe}-\mathrm{MnO}_{x}\right)$, and hematite $\left(\mathrm{Hem}-\mathrm{MnO}_{x}\right)$, respectively (Figure S6). The three Fe-Mn binary oxides showed specific surface areas different from their corresponding single Fe and Mn oxides. Specific As(III) adsorption capacities (per unit surface area of absorbent), representing the intrinsic adsorption ability of Fe-Mn binary oxides, were therefore compared. As shown in Figure S6a, the specific As(III) adsorption capacity of binary Hem- $\mathrm{MnO}_{x}$ samples $\left(3.12 \mu \mathrm{mol} \mathrm{m}{ }^{-2}\right)$ was greater adsorption capacity $\left(0.62 \mu \mathrm{mol} \mathrm{m} \mathrm{m}^{-2}\right)$ was slightly lower than that of single goethite $\left(0.78 \mu \mathrm{mol} \mathrm{m} \mathrm{m}^{-2}\right)$ (Figure S6b). For binary Fe-MnO $\mathrm{Mn}_{x}$ samples, specific As(III) adsorption capacity $\left(3.31 \mu \mathrm{mol} \mathrm{m}{ }^{-2}\right.$ ) was lower than that of single ferrihydrite $\left(3.53 \mu \mathrm{mol} \mathrm{m} \mathrm{m}^{-2}\right)$ (Figure S6b). This further demonstrates that both synergistic and antagonistic effects between Fe and Mn oxides in binary oxides exist for As(III) removal. contaminated groundwater.

In situ flow ATR-FTIR. To reveal the sorption and redox behaviors of As(III) within single iron oxide observed in the entire reaction time, suggesting that $\mathrm{As}(\mathrm{III})$ had not transferred to $\mathrm{As}(\mathrm{V})$ by ferrihydrite in this case. For single hematite reacted with As(III), As(III) was also the main As species adsorbed, 
244 evidenced by the IR adsorption peak around $802 \mathrm{~cm}^{-1}$ (Figure 3b). However, the intensity of As(III) characteristic adsorption peak in hematite was not as strong as that in ferrihydrite, suggesting that the

246 affinity of As(III) in ferrihydrite was stronger than that in hematite, which was in agreement with 247 adsorption isotherm data. Interestingly, for mixed Fe and Mn oxide systems, two IR adsorption peaks at $\sim 817$ and $\sim 798 \mathrm{~cm}^{-1}$, which were assigned to $\mathrm{As}(\mathrm{III})$ and $\mathrm{As}(\mathrm{V})$ species, respectively, were observed simultaneously and became stronger with increasing reaction time (Figure $3 \mathrm{c}$ and $\mathrm{d}$ ). This result revealed that $\mathrm{Mn}$ oxide led to the rapid transformation of $\mathrm{As}(\mathrm{III})$ to $\mathrm{As}(\mathrm{V})$, which may play an indirect role in

Aqueous arsenic dynamics within Donnan reactor. To further illustrate the different working hematite, which showed opposite adsorption affinities to both $\mathrm{As}(\mathrm{III})$ and $\mathrm{As}(\mathrm{V})$, were used to perform oxide there was a slight increase (Figure 4a), suggesting that most of the As(III) species may be rapidly adsorbed by ferrihydrite without further diffusion into the Mn oxide chamber. After $10 \mathrm{~h}$, As concentration reached equilibrium in the two chambers (Figure 4a). However, As concentration in the Mn oxide chamber decreased slowly after addition of As(III) (Figure 4b). The decrease in As concentration in the Mn oxide chamber mainly depended on As diffusion transport between the neighboring chambers. Arsenite had undergone oxidation, diffusion, and adsorption, which was more 
complex than when it was applied to the ferrihydrite chamber. Equilibrium was reached after $\sim 36 \mathrm{~h}$

(Figure 4b). Addition of As(III) to the manganese oxide chamber reached an As concentration of 29.2 $\mu \mathrm{mol} \mathrm{L}{ }^{-1}$, whereas in the ferrihydrite chamber only $20.0 \mu \mathrm{mol} \mathrm{L}-1$ was reached (Figure S8a). This result indicates that the antagonistic effect between ferrihydrite and Mn oxide in Fe-Mn oxide systems may be attributed to pre-treatment of As(III) by Mn oxide.

In the hematite chamber, the decrease in As concentration was not as rapid as that in the ferrihydrite chamber (Figure 4c). This may be due to the weak adsorption of As(III) on hematite and the slow diffusion of As(III) into the Mn oxide chamber. Arsenite, in the Mn oxide chamber, had undergone oxidation, diffusion, and adsorption processes, and equilibrium was reached after $\sim 24 \mathrm{~h}$. Pretreatment of As(III) by Mn oxide also increased As removal in the hematite-Mn oxide system (Figure S8b). However, the aqueous As concentration in the Donnan reactor was close to each other with increasing reaction time. This observation could be explained by the high affinity of $\mathrm{As}(\mathrm{V})$ in hematite compared to As(III), which will be discussed further in XPS analysis (see XPS analysis section).

Surface analysis of Fe and Mn oxides in Donnan experiments. To reveal the evolution of surface speciation of Fe, Mn and As during the processes of As(III) sorption and redox in the Donnan reactor, the surface compositions of Fe and Mn oxides in the chambers were investigated by analyzing their XPS spectra. Figure 5 reveals Fe2p spectra of the iron oxides before and after reaction with As in the chambers. As shown in Figure 5c, Fe(III) was the dominant Fe species that existed on ferrihydrite surfaces, evidenced by the peak shape and the binding energy of $\sim 711.0 \mathrm{eV}[19,42]$. There was no obvious change of binding energy in Fe2p spectra when As(III) was added into ferrihydrite and Mn oxide chambers (Figure 5a and b). However, a decrease in Fe2p spectra intensity appeared after reaction with As (Figure 5a and b). This observation also appeared when As(III) was added into hematite and manganese oxide 
chambers (Figure 5d and e), suggesting the existence of a strong interaction between Fe oxide and As species $[19,29,43]$.

Mn2p spectra of Mn oxides before and after reaction with As(III) in the chambers is shown in Figure S9. With addition of As(III) into the Mn oxide chamber, the binding energy of Mn2p3/2 spectra decreased from 642.5 to $642.1 \mathrm{eV}$ relative to fresh Mn oxide (Figure S9b and c). This may be explained by an increase in the fraction of reduced Mn species relative to $\mathrm{Mn}(\mathrm{IV})$ originating from As(III) oxidation by Mn oxide [44-46]. Addition of As(III) into the ferrihydrite chamber also decreased the binding energy of Mn2p3/2 spectra, indicating that there was partial diffusion of As(III) species into the Mn oxide chamber which subsequently reacted with Mn oxide to reduce the oxidation state of Mn species (Figure S9a). A decrease in binding energy, but with no obvious intensity change of Mn2p spectra in Mn oxide, was observed when addition of As(III) was added into both hematite and Mn oxide chambers (Figure S9d and e), suggesting that Mn oxide mainly responds to oxidation of As(III), rather than adsorption in this case.

Spectra for As3d species adsorbed by Fe and Mn oxides is shown in Figure 6. With addition of As(III) in the ferrihydrite chamber, As3d binding energy was $~ 44.3 \mathrm{eV}$ (Figure 6a) $[45,46]$. With As(III), the As3d binding energy significantly increased from $\sim 44.3$ to $\sim 45.5 \mathrm{eV}$ (Figure $6 \mathrm{~b}$ ). According to previous literature, As3d binding energy at $45.2 \sim 45.6 \mathrm{eV}$ in arsenic oxide is attributed to As(V) species [19, 43, 44, 46]. This indicated that As(III) was rapidly oxidized to As(V) by Mn oxide, subsequently diffusing into the ferrihydrite chamber, followed by adsorption onto ferrihydrite. The main As species adsorbed by Mn oxide was As(V), evidenced by the As3d binding energy of $\sim 45.5 \mathrm{eV}$ (Figure 6a and b) [45]. However, the As3d spectra intensity of As species adsorbed by Mn oxide was lower than that of ferrihydrite, suggesting that Mn oxide was not responsible for As adsorption, which was consistent with 
both adsorption isotherm data and Mn2p XPS spectra analysis. In the hematite chamber, As3d binding energy was $\sim 45.5 \mathrm{eV}$ (Figure 6c). Arsenic species adsorbed by hematite were mainly As(V) (Figure 6a). Unlike ferrihydrite, hematite adsorbed only a small amount of As(III). Unadsorbed As(III) slowly diffused into the Mn oxide chamber and may subsequently have been oxidized to $\operatorname{As}(\mathrm{V})$. Total As adsorbed by hematite was the same after the reaction reached equilibrium no matter which chamber As(III) was added to, and was confirmed by As3d spectra intensity. This phenomenon also explained above discussion, it may be concluded that As(III) oxidation mediated by manganese oxide in Fe-Mn oxides is not suitable for all Fe-Mn binary oxides. adsorption on ferrihydrite should not be ignored, because both Fe and Mn oxides usually coexist in a 
332 (hydr-)oxide in reduced groundwater. In addition, this finding provides a new insight into the working

333 relationships between Fe and Mn oxides for As removal, which should aid in the rational design and

334 adequate selection of highly efficient absorbents of Fe-Mn binary oxides for treating real As

335 contaminated groundwater.

\section{ASSOCIATED CONTENT}

\section{S Supporting Information.}

338 XRD, EDS data, SEM images, Langmuir and Freundlich isotherm parameters for As(III) and As(V), specific surface areas, FTIR spectra, aqueous arsenic concentration in Donnan reactor, Mn2p XPS spectra

340 profiles of the samples are available free of charge via the Internet at http://pubs.acs.org.

\section{AUTHOR INFORMATION}

\section{Corresponding Author}

343 *Jingtao Hou; Email: houjt87@163.com

344 *Shuxin Tu; Email: stu@mail.hzau.edu.cn

$345 \quad$ Notes

346 The authors declare no competing financial interest.

\section{ACKNOWLEDGMENT}

348 This work was supported by National Natural Science Foundation of China (41571229, 41977022), National Key Research and Development Program of China (2018YFC1800305), Hubei

350 Provincial Natural Science Foundation of China (2018CFB627), and the Fundamental Research 
353

1. Smedley, P. L.; Kinniburgh, D. G., A review of the source, behaviour and distribution of arsenic in natural waters. Appl. Geochem. 2002, 17, (5), 517-568.

2. Choong, T. S.; Chuah, T.; Robiah, Y.; Koay, F. G.; Azni, I., Arsenic toxicity, health hazards and removal techniques from water: an overview. Desalination 2007, 217, (1-3), 139-166.

3. Edition, F., Guidelines for drinking-water quality. WHO chronicle 2011, 38, (4), 104-8.

4. Gorny, J.; Billon, G.; Lesven, L.; Dumoulin, D.; Made, B.; Noiriel, C., Arsenic behavior in river sediments under redox gradient: A review. Sci. Total Environ. 2015, 505, 423-434.

5. Gupta, K.; Bhattacharya, S.; Chattopadhyay, D.; Mukhopadhyay, A.; Biswas, H.; Dutta, J.; Ray, N. R.; Ghosh, U. C., Ceria associated manganese oxide nanoparticles: Synthesis, characterization and arsenic(V) sorption behavior. Chem. Eng. J. 2011, 172, (1), 219-229.

6. Gupta, K.; Bhattacharya, S.; Nandi, D.; Dhar, A.; Maity, A.; Mukhopadhyay, A.; Chattopadhyay, D. J.; Ray, N. R.; Sen, P.; Ghosh, U. C., Arsenic(III) sorption on nanostructured cerium incorporated manganese oxide (NCMO): A physical insight into the mechanistic pathway. J. Colloid Interface Sci. 2012, 377, 269-276.

7. Chen, J.; Wang, J. Y.; Zhang, G. S.; Wu, Q. Y.; Wang, D. T., Facile fabrication of nanostructured cerium-manganese binary oxide for enhanced arsenite removal from water. Chem. Eng. J. 2018, $334,1518-1526$.

8. Zhang, G. S.; Khorshed, A.; Chen, J. P., Simultaneous removal of arsenate and arsenite by a nanostructured zirconium-manganese binary hydrous oxide: Behavior and mechanism. J. Colloid Interface Sci. 2013, 397, 137-143.

9. Yin, Y. W.; Zhou, T. T.; Luo, H. J.; Geng, J. J.; Yu, W. Y.; Jiang, Z. J., Adsorption of arsenic by 
activated charcoal coated zirconium-manganese nanocomposite: Performance and mechanism. Colloid Surf. A-Physicochem. Eng. Asp. 2019, 575, 318-328.

10. Cai, X. J.; Li, Y.; Guo, J. W.; Liu, S.; Na, P., Mn(IV) promotion mechanism for the photocatalytic oxidation of arsenite by anatase-TiO2. Chem. Eng. J. 2014, 248, 9-17.

11. Zhang, W.; Zhang, G. S.; Liu, C. H.; Li, J.; Zheng, T.; Ma, J.; Wang, L.; Jiang, J.; Zhai, X. D., Enhanced removal of arsenite and arsenate by a multifunctional Fe-Ti-Mn composite oxide: Photooxidation, oxidation and adsorption. Water Res. 2018, 147, 264-275.

12. Zhang, W.; Liu, C. H.; Zheng, T.; Ma, J.; Zhang, G. S.; Ren, G. H.; Wang, L.; Liu, Y. L., Efficient oxidation and sorption of arsenite using a novel titanium(IV)-manganese(IV) binary oxide sorbent. J. Hazard. Mater. 2018, 353, 410-420.

13. Li, X.; He, K.; Pan, B. C.; Zhang, S. J.; Lu, L.; Zhang, W. M., Efficient As(III) removal by macroporous anion exchanger-supported Fe-Mn binary oxide: Behavior and mechanism. Chem. Eng. J. 2012, 193, 131-138.

14. Zhang, G. S.; Liu, H. J.; Qu, J. H.; Jefferson, W., Arsenate uptake and arsenite simultaneous sorption and oxidation by Fe-Mn binary oxides: Influence of $\mathrm{Mn} / \mathrm{Fe}$ ratio, $\mathrm{pH}, \mathrm{Ca} 2+$, and humic acid. J. Colloid Interface Sci. 2012, 366, (1), 141-146.

15. Zhu, J.; Baig, S. A.; Sheng, T. T.; Lou, Z. M.; Wang, Z. X.; Xu, X. H., Fe3O4 and MnO2 assembled on honeycomb briquette cinders (HBC) for arsenic removal from aqueous solutions. J. Hazard. Mater. 2015, 286, 220-228.

16. Xu, F. N.; Chen, H. X.; Dai, Y. X.; Wu, S. L.; Tang, X. J., Arsenic adsorption and removal by a new starch stabilized ferromanganese binary oxide in water. J. Environ. Manage. 2019, 245, 160 167. 
17. Wu, K.; Liu, T.; Xue, W.; Wang, X. C., Arsenic(III) oxidation/adsorption behaviors on a new bimetal adsorbent of Mn-oxide-doped Al oxide. Chem. Eng. J. 2012, 192, 343-349.

18. Wu, K.; Zhang, N.; Liu, T.; Ma, C.; Jin, P. K.; Zhang, F. R.; Zhang, J.; Wang, X. C., Competitive adsorption behaviors of arsenite and fluoride onto manganese-aluminum binary adsorbents. Colloid Surf. A-Physicochem. Eng. Asp. 2017, 529, 185-194.

19. Zhang, G. S.; Qu, J. H.; Liu, H. J.; Liu, R. P.; Li, G. T., Removal mechanism of As(III) by a novel Fe-Mn binary oxide adsorbent: Oxidation and sorption. Environ. Sci. Technol. 2007, 41, (13), 4613-4619.

20. Zhang, G. S.; Liu, H. J.; Liu, R. P.; Qu, J. H., Adsorption behavior and mechanism of arsenate at Fe-Mn binary oxide/water interface. J. Hazard. Mater. 2009, 168, (2-3), 820-825.

21. Ocinski, D.; Jacukowicz-Sobala, I.; Mazur, P.; Raczyk, J.; Kociolek-Balawejder, E., Water treatment residuals containing iron and manganese oxides for arsenic removal from water Characterization of physicochemical properties and adsorption studies. Chem. Eng. J. 2016, 294, $210-221$

22. Bai, Y. H.; Yang, T. T.; Liang, J. S.; Qu, J. H., The role of biogenic Fe-Mn oxides formed in situ for arsenic oxidation and adsorption in aquatic ecosystems. Water Res. 2016, 98, 119-127.

23. Raven, K. P.; Jain, A.; Loeppert, R. H., Arsenite and arsenate adsorption on ferrihydrite: Kinetics, equilibrium, and adsorption envelopes. Environ. Sci. Technol. 1998, 32, (3), 344-349.

24. Zhang, G. S.; Liu, F. D.; Liu, H. J.; Qu, J. H.; Liu, R. P., Respective Role of Fe and Mn Oxide Contents for Arsenic Sorption in Iron and Manganese Binary Oxide: An X-ray Absorption Spectroscopy Investigation. Environ. Sci. Technol. 2014, 48, (17), 10316-10322.

25. Wen, Z. P.; Zhang, Y. L.; Zhou, X. F.; Chen, R., Effective As(III) and As(V) immobilization 

from aqueous solution by nascent ferrous hydroxide colloids (FHC). Sep. Purif. Technol. 2017, 176, $395-401$

26. Kong, S. Q.; Wang, Y. X.; Hu, Q. H.; Olusegun, A. K., Magnetic nanoscale Fe-Mn binary oxides loaded zeolite for arsenic removal from synthetic groundwater. Colloid Surf. A-Physicochem. Eng. Asp. 2014, 457, 220-227.

27. Cui, H. J.; Cai, J. K.; Zhao, H.; Yuan, B. L.; Ai, C. L.; Fu, M. L., Fabrication of magnetic porous Fe-Mn binary oxide nanowires with superior capability for removal of As(III) from water. J. Hazard. Mater. 2014, 279, 26-31.

28. McCann, C. M.; Peacock, C. L.; Hudson-EdWards, K. A.; Shrimpton, T.; Gray, N. D.; Johnson, K. L., In situ arsenic oxidation and sorption by a Fe-Mn binary oxide waste in soil. J. Hazard. Mater. 2018, 342, 724-731.

29. Zhang, G. S.; Qu, J. H.; Liu, H. J.; Liu, R. P.; Wu, R. C., Preparation and evaluation of a novel Fe-Mn binary oxide adsorbent for effective arsenite removal. Water Res. 2007, 41, (9), 1921-1928. 30. Ying, S. C.; Kocar, B. D.; Fendorf, S., Oxidation and competitive retention of arsenic between iron- and manganese oxides. Geochim. Cosmochim. Acta 2012, 96, 294-303.

31. Redman, A. D.; Macalady, D. L.; Ahmann, D., Natural organic matter affects arsenic speciation and sorption onto hematite. Environ. Sci. Technol. 2002, 36, (13), 2889-2896.

32. Hong, J.; Liu, L. H.; Luo, Y.; Tan, W. F.; Qiu, G. H.; Liu, F., Photochemical oxidation and dissolution of arsenopyrite in acidic solutions. Geochim. Cosmochim. Acta 2018, 239, 173-185.

33. Tang, W. S.; Li, Q.; Gao, S. A.; Shang, J. K., Arsenic (III, V) removal from aqueous solution by ultrafine alpha-Fe2O3 nanoparticles synthesized from solvent thermal method. J. Hazard. Mater. 2011, 192, (1), 131-138. 
34. Manning, B. A.; Fendorf, S. E.; Bostick, B.; Suarez, D. L., Arsenic(III) oxidation and arsenic(V) adsorption reactions on synthetic birnessite. Environ. Sci. Technol. 2002, 36, (5), 976-981.

35. Lafferty, B. J.; Ginder-Vogel, M.; Zhu, M. Q.; Livi, K. J. T.; Sparks, D. L., Arsenite Oxidation by a Poorly Crystalline Manganese-Oxide. 2. Results from X-ray Absorption Spectroscopy and Xray Diffraction. Environ. Sci. Technol. 2010, 44, (22), 8467-8472.

36. Hou, J. T.; Luo, J. L.; Hu, Z. Q.; Li, Y. Z.; Mao, M. Y.; Song, S. X.; Liao, Q. L.; Li, Q. Z., Tremendous effect of oxygen vacancy defects on the oxidation of arsenite to arsenate on cryptomelane-type manganese oxide. Chem. Eng. J. 2016, 306, 597-606.

37. Hou, J. T.; Xiang, Y. J.; Zheng, D.; Li, Y. Z.; Xue, S. G.; Wu, C.; Hartley, W.; Tan, W. F., Morphology-dependent enhancement of arsenite oxidation to arsenate on birnessite-type manganese oxide. Chem. Eng. J. 2017, 327, 235-243.

38. Voegelin, A.; Hug, S. J., Catalyzed oxidation of arsenic(III) by hydrogen peroxide on the surface of ferrihydrite: An in situ ATR-FTIR study. Environ. Sci. Technol. 2003, 37, (5), 972-978.

39. Parikh, S. J.; Lafferty, B. J.; Sparks, D. L., An ATR-FTIR spectroscopic approach for measuring rapid kinetics at the mineral/water interface. J. Colloid Interface Sci. 2008, 320, (1), 177-185.

40. Lan, S.; Ying, H.; Wang, X. M.; Liu, F.; Tan, W. F.; Huang, Q. Y.; Zhang, J.; Feng, X. H., Efficient catalytic As(III) oxidation on the surface of ferrihydrite in the presence of aqueous Mn(II). Water Res. 2018, 128, 92-101.

41. Hou, J. T.; Sha, Z. J.; Hartley, W.; Tan, W. F.; Wang, M. X.; Xiong, J.; Li, Y. Z.; Ke, Y. J.; Long, Y.; Xue, S. G., Enhanced oxidation of arsenite to arsenate using tunable $\mathrm{K}+$ concentration in the OMS-2 tunnel. Environ. Pollut. 2018, 238, 524-531.

42. Wen, Z. P.; Zhang, Y. L.; Wang, Y.; Li, L. N.; Chen, R., Redox transformation of arsenic by 
magnetic thin-film MnO2 nanosheet-coated flowerlike Fe3O4 nanocomposites. Chem. Eng. J. 2017, $312,39-49$

43. Zhang, Y.; Yang, M.; Dou, X. M.; He, H.; Wang, D. S., Arsenate adsorption on an Fe-Ce bimetal oxide adsorbent: Role of surface properties. Environ. Sci. Technol. 2005, 39, (18), 7246-7253.

44. Nesbitt, H. W.; Canning, G. W.; Bancroft, G. M., XPS study of reductive dissolution of 7 angstrom-birnessite by $\mathrm{H} 3 \mathrm{AsO} 3$, with constraints on reaction mechanism. Geochim. Cosmochim. Acta 1998, 62, (12), 2097-2110.

45. Lafferty, B. J.; Ginder-Vogel, M.; Sparks, D. L., Arsenite Oxidation by a Poorly-Crystalline Manganese Oxide. 3. Arsenic and Manganese Desorption. Environ. Sci. Technol. 2011, 45, (21), 9218-9223.

46. Hou, J. T.; Luo, J. L.; Song, S. X.; Li, Y. Z.; Li, Q. Z., The remarkable effect of the coexisting arsenite and arsenate species ratios on arsenic removal by manganese oxide. Chem. Eng. J. 2017, $315,159-166$.

47. Chakravarty, S.; Dureja, V.; Bhattacharyya, G.; Maity, S.; Bhattacharjee, S., Removal of arsenic from groundwater using low cost ferruginous manganese ore. Water Res. 2002, 36, (3), 625-632.

48. Chang, F. F.; Qu, J. H.; Liu, R. P.; Zhao, X.; Lei, P. J., Practical performance and its efficiency of arsenic removal from groundwater using Fe-Mn binary oxide. J. Environ. Sci. 2010, 22, (1), 1-6.

\section{Table and Figure Captions:}

Figure 1. Schematic illustration of the Donnan reactor composed of two reaction cells separated by a semi-permeable membrane, where Fe and Mn oxides were placed into two chambers, respectively.

Figure 2. Adsorption isotherms for $\mathrm{As}(\mathrm{III})$ and $\mathrm{As}(\mathrm{V})$ by hematite (a), goethite (b), ferrihydrite (c), the 
mixtures of hematite and $\mathrm{MnO}_{x}(\mathrm{~d})$, goethite and $\mathrm{MnO}_{x}(\mathrm{e})$, and ferrihydrite and $\mathrm{MnO}_{x}(\mathrm{f})$ with a 100 $\mathrm{mg} \mathrm{L}^{-1}$ suspension at $\mathrm{pH} 7.0$.

Figure 3. Time-dependence of in suit flow ATR-FTIR spectra of ferrihydrite (a), hematite (b), the mixed ferrihydrite and $\mathrm{MnO}_{x}(\mathrm{c})$, and the mixed hematite and $\mathrm{MnO}_{x}(\mathrm{~d})$ reacted with $1 \mathrm{mM}$ of As(III) solution at $\mathrm{pH} 7.0$.

Figure 4. The evolution of aqueous arsenic concentration in Fe and Mn oxide chambers as a function of time within ferrihydrite-Mn oxide (a, b) and hematite-Mn oxide (c, d) systems at $\mathrm{pH}=7$. The dosage of Fe and Mn oxides in chambers was $100 \mathrm{mg} \mathrm{L}^{-1}$. The As(III) concentration added in ferrihydrite-Mn oxide and hematite-Mn oxide systems was 133.3 and $26.7 \mu \mathrm{M}$, respectively.

Figure 5. The Fe2p XPS spectra of the iron oxides in ferrihydrite-Mn oxide (a, b, c) and hematite-Mn oxide (d, e, f) systems before and after adding As(III) in Fe or Mn oxides chambers.

Figure 6. The As3d XPS spectra of the arsenic species adsorbed by iron or Mn oxides in ferrihydriteMn oxide ( $a, b)$ and hematite-Mn oxide (c, d) systems after adding As(III) into Fe or Mn oxide chambers. 


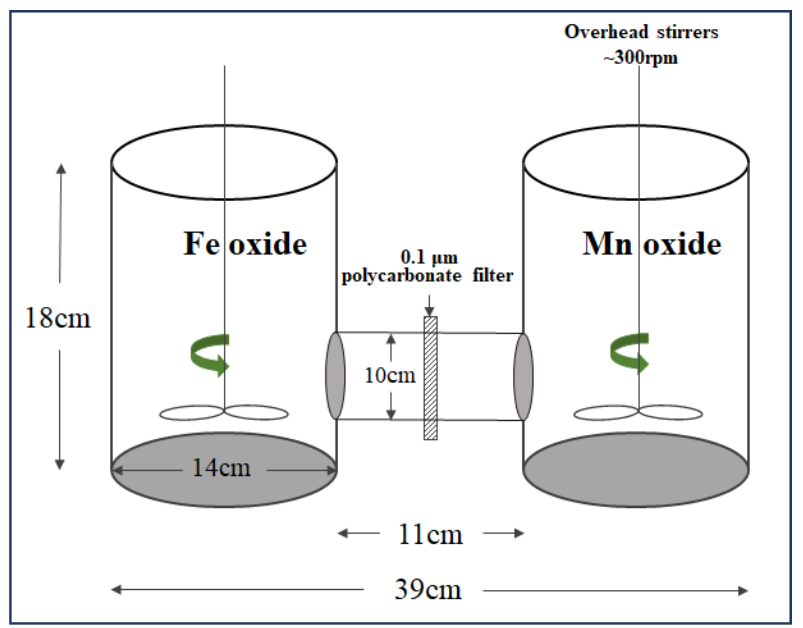

502 Figure 1. Schematic illustration of the Donnan reactor composed of two reaction cells separated by a

503 semi-permeable membrane, where Fe and Mn oxides were placed into two chambers, respectively.
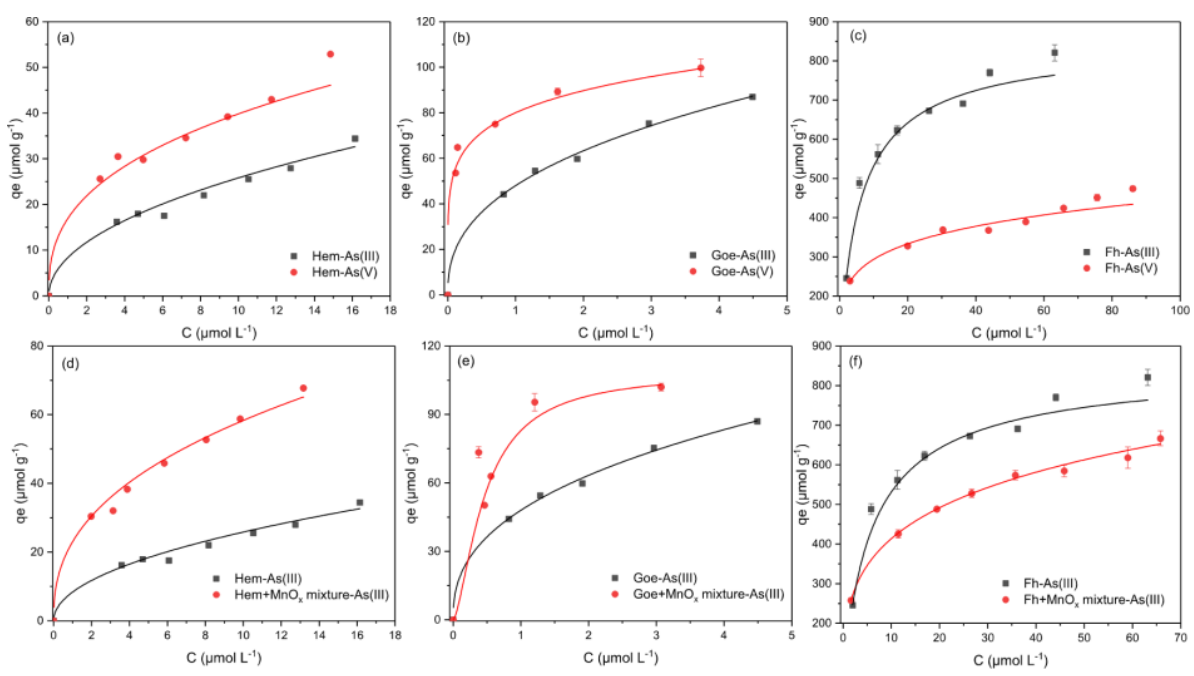

506 Figure 2. Adsorption isotherms for $\mathrm{As}(\mathrm{III})$ and $\mathrm{As}(\mathrm{V})$ by hematite (a), goethite (b), ferrihydrite (c),

507 mixtures of hematite and $\mathrm{MnO}_{x}(\mathrm{~d})$, goethite and $\mathrm{MnO}_{x}(\mathrm{e})$, and ferrihydrite and $\mathrm{MnO}_{x}$ (f) with a 100 mg L $\mathrm{L}^{-1}$ suspension at $\mathrm{pH}$ 7.0. 

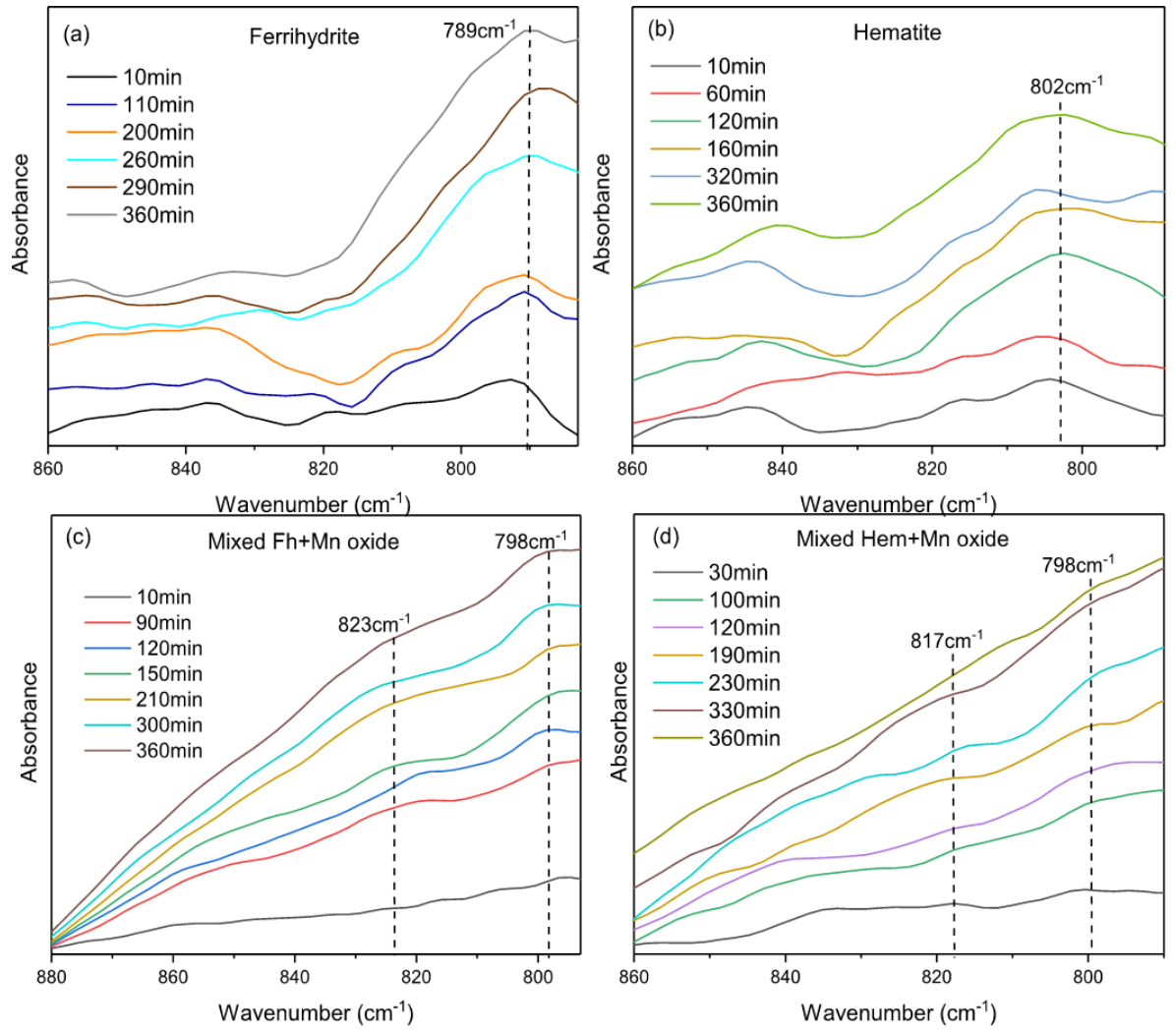

510 Figure 3. Time-dependence of in suit flow ATR-FTIR spectra of ferrihydrite (a), hematite (b), mixed

511 ferrihydrite and $\mathrm{MnO}_{x}(\mathrm{c})$, mixed hematite and $\mathrm{MnO}_{x}(\mathrm{~d})$ reacted with $1 \mathrm{mM}$ of $\mathrm{As}(\mathrm{III})$ solution at $\mathrm{pH}$
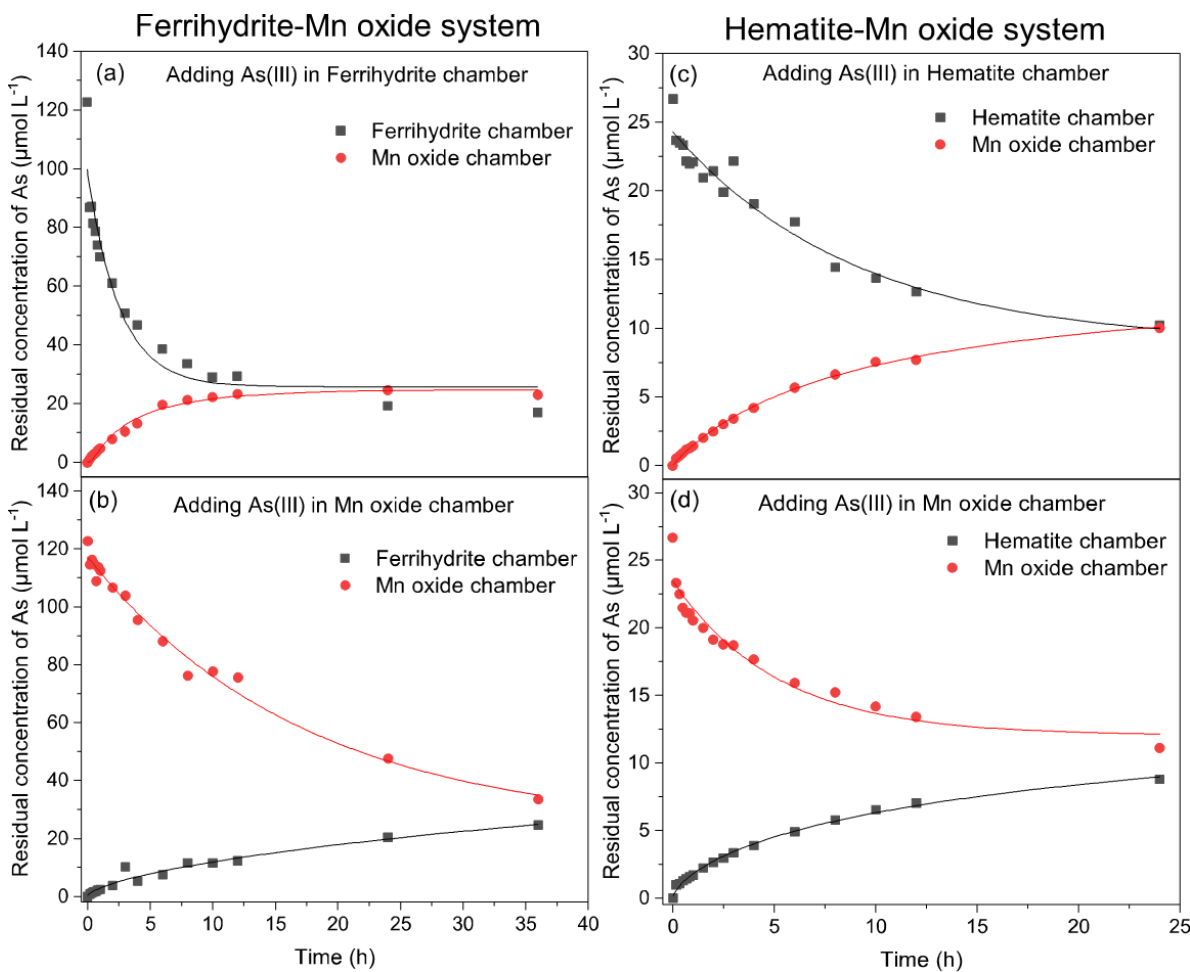
514 Figure 4. Evolution of aqueous As concentration in Fe and Mn oxide chambers as a function of time and Mn oxides in chambers was $100 \mathrm{mg} \mathrm{L}^{-1}$. The As(III) concentration added in ferrihydrite-Mn oxide and hematite-Mn oxide systems was 133.3 and $26.7 \mu \mathrm{M}$, respectively.
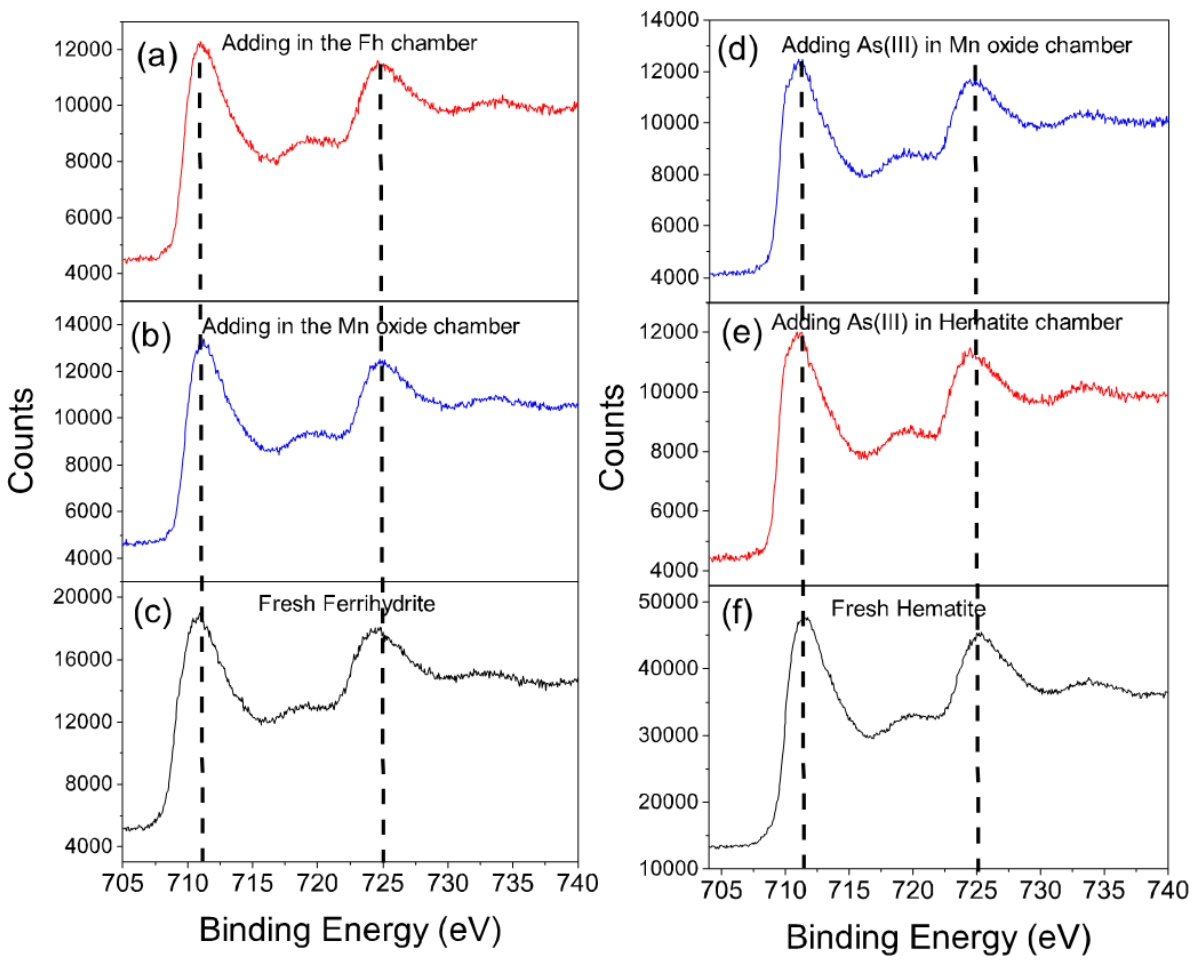

520 Figure 5. Fe2p XPS spectra of iron oxides in ferrihydrite-Mn oxide (a, b, c) and hematite-Mn oxide (d,

e, f) systems before and after adding As(III) in Fe or Mn oxide chambers. 

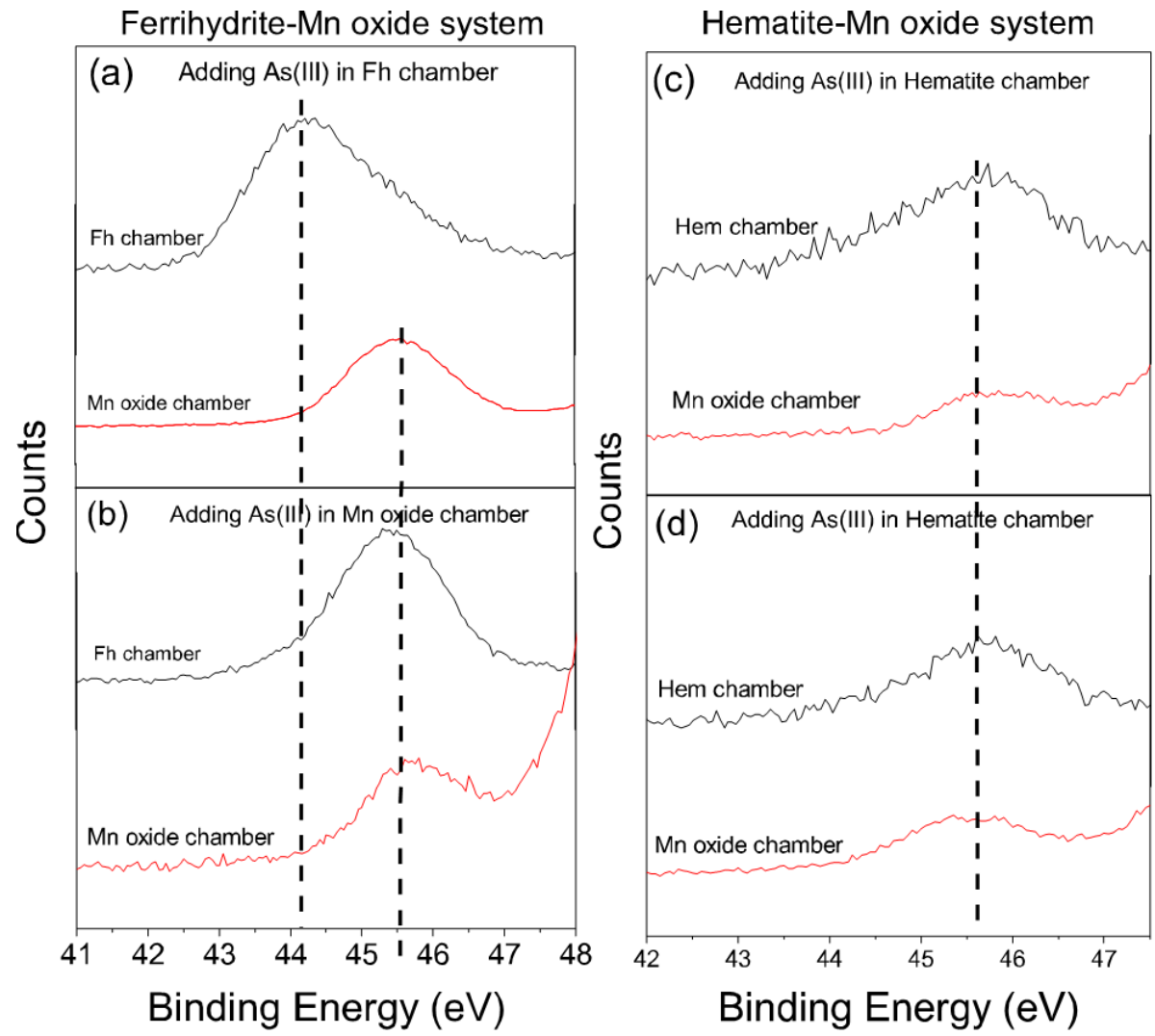

Figure 6. As3d XPS spectra of As species adsorbed by iron or Mn oxides in ferrihydrite-Mn oxide (a, 
As(III) adsorption on Fe-Mn binary oxides: Are manganese oxide and iron oxide synergistic or antagonistic for arsenic removal?

Qian Zheng, ${ }^{\dagger}$ Jingtao Hou, ${ }^{\dagger, *}$ Mingxia Wang, ${ }^{\dagger}$ Shuxin Tu, ${ }^{\dagger, *}$ Wenfeng Tan ${ }^{\dagger}$

551

552

553

554

555

556

557

558

559

560

561

562

563

564

565

566

567

568

569

570

571

572

573

574

575

576

577

578

579

580

Pages: 4

Tables: 3

Figures: 6

*Corresponding author: *Jingtao Hou; Email: houjt87@163.com

*Shuxin Tu; Email: stu@mail.hzau.edu.cn 
Table S1. EDS data of Fe and Mn elemental content in different Fe-Mn binary oxides.

\begin{tabular}{|c|c|c|c|c|c|c|c|c|}
\hline \multirow{3}{*}{$\begin{array}{c}\text { Fe-Mn } \\
\text { binary } \\
\text { oxides }\end{array}$} & \multicolumn{8}{|c|}{ Elements } \\
\hline & \multicolumn{2}{|c|}{$\mathrm{Fe} \mathrm{K}$} & \multicolumn{2}{|c|}{ Mn K } & \multicolumn{2}{|c|}{$\mathrm{C} \mathrm{k}$} & \multicolumn{2}{|c|}{$\mathrm{OK}$} \\
\hline & $\begin{array}{c}\text { Weight } \\
(\%)\end{array}$ & $\begin{array}{c}\text { Atomic } \\
(\%)\end{array}$ & $\begin{array}{c}\text { Weight } \\
(\%)\end{array}$ & $\begin{array}{c}\text { Atomic } \\
(\%)\end{array}$ & $\begin{array}{c}\text { Weight } \\
(\%)\end{array}$ & $\begin{array}{c}\text { Atomic } \\
(\%)\end{array}$ & $\begin{array}{c}\text { Weight } \\
(\%)\end{array}$ & $\begin{array}{c}\text { Atomic } \\
(\%)\end{array}$ \\
\hline Hem- $\mathrm{MnO}_{\mathrm{x}}$ & 38.09 & 17.12 & 14.75 & 6.74 & 4.09 & 8.54 & 43.07 & 67.59 \\
\hline Goe- $\mathrm{MnO}_{\mathrm{x}}$ & 69.66 & 56.29 & 20.59 & 16.91 & 0.58 & 0.93 & 9.17 & 25.87 \\
\hline Fh- $\mathrm{MnO}_{\mathrm{x}}$ & 44.87 & 21.01 & 11.34 & 5.4 & 3.67 & 8 & 40.12 & 65.59 \\
\hline
\end{tabular}

582

Table S3. Langmuir and Freundlich isotherm parameters for As(III) and As(V) adsorption on single

Table S2. Specific surface areas (SSA) of the samples.

\begin{tabular}{cc}
\hline Samples & Specific surface areas $\left(\mathrm{m}^{2} \mathrm{~g}^{-1}\right)$ \\
\hline Hematite & 38.9 \\
Goethite & 143.3 \\
Ferrihydrite & $247.0^{*}$ \\
Manganese oxide & 46.5 \\
Hem-MnO & 32.8 \\
${\text { Goe- } \mathrm{MnO}_{\mathrm{x}}}_{\text {Fh- }_{\mathrm{MnO}}}$ & 213.3 \\
\hline
\end{tabular}

*Data was cited from previous work reported by Zhang et al (J Hazard. Mater. 2009, 168, 820-825).

iron oxide, manganese oxide, Fe-Mn binary oxides, and mixed Fe and Mn oxides at pH 7.0.

\begin{tabular}{|c|c|c|c|c|c|c|c|}
\hline \multirow[b]{2}{*}{$\begin{array}{c}\text { As } \\
\text { species }\end{array}$} & \multirow[b]{2}{*}{ Adsorbents } & \multicolumn{3}{|c|}{ Langmuir model } & \multicolumn{3}{|c|}{ Freundlich model } \\
\hline & & $\begin{array}{c}\mathrm{q}_{\mathrm{m}} \\
\left(\mu \mathrm{mol} \mathrm{g} \mathrm{g}^{-1}\right)\end{array}$ & $\begin{array}{c}\mathrm{b} \\
\left(\mathrm{L} \mathrm{mol}^{-1}\right)\end{array}$ & $R^{2}$ & $\begin{array}{c}\mathrm{K}_{\mathrm{F}} \\
\left(\mathrm{L} \mathrm{mol}^{-1}\right)\end{array}$ & $\mathrm{n}$ & $R^{2}$ \\
\hline \multirow{10}{*}{$\mathrm{As}(\mathrm{III})$} & Hematite & 51.2 & 1.4 & 0.892 & 2.2 & 0.5 & 0.942 \\
\hline & Goethite & 112.8 & 0.1 & 0.988 & 10.1 & 0.4 & 0.991 \\
\hline & Ferrihydrite & 871.5 & 2.1 & 0.993 & 40.3 & 0.3 & 0.917 \\
\hline & $\mathrm{MnO}_{x}$ & 9.5 & 4.1 & 0.533 & 2.5 & 0.9 & 0.913 \\
\hline & Mixed $\mathrm{Hem}+\mathrm{MnO}_{2}$ & 90.7 & 2.6 & 0.969 & 4.5 & 0.5 & 0.977 \\
\hline & Mixed Goe $+\mathrm{MnO}_{2}$ & 116.3 & 33.7 & 0.981 & 11.9 & 0.3 & 0.644 \\
\hline & Mixed $\mathrm{Fh}+\mathrm{MnO}_{2}$ & 694.4 & 2.0 & 0.989 & 33.0 & 0.3 & 0.996 \\
\hline & Binary Hem- $\mathrm{MnO}_{x}$ oxide & 102.3 & 4.3 & 0.989 & 6.8 & 0.4 & 0.996 \\
\hline & Binary Goe- $\mathrm{MnO}_{x}$ oxide & 131.5 & 33.8 & 0.997 & 10.1 & 0.2 & 0.988 \\
\hline & Binary Fh- $\mathrm{MnO}_{x}$ oxide & 883.1 & 2.3 & 0.980 & 44.1 & 0.3 & 0.983 \\
\hline \multirow{4}{*}{$\operatorname{As}(\mathrm{V})$} & Hematite & 65.3 & 2.6 & 0.930 & 3.5 & 0.4 & 0.934 \\
\hline & Goethite & 102.7 & 81.2 & 0.997 & 9.2 & 0.2 & 0.946 \\
\hline & Ferrihydrite & 493.9 & 1.4 & 0.976 & 23.3 & 0.2 & 0.963 \\
\hline & $\mathrm{MnO}_{x}$ & 2.8 & 0.01 & 0.844 & 7.9 & 0.6 & 0.938 \\
\hline
\end{tabular}



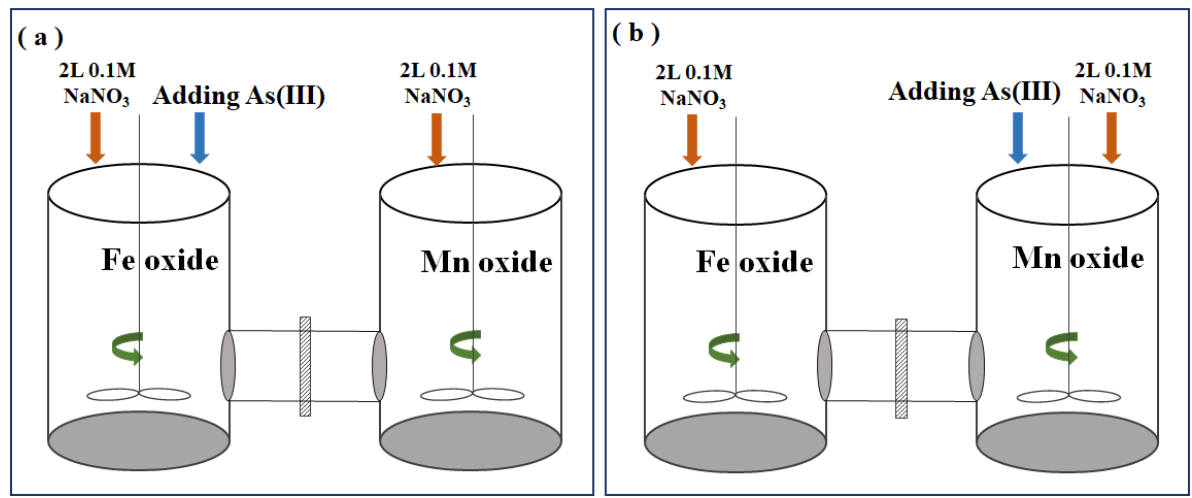

Figure S1. Schematic illustration of addition of As(III) solution into Fe oxide (a) and Mn oxide (b)

591 chambers, respectively.
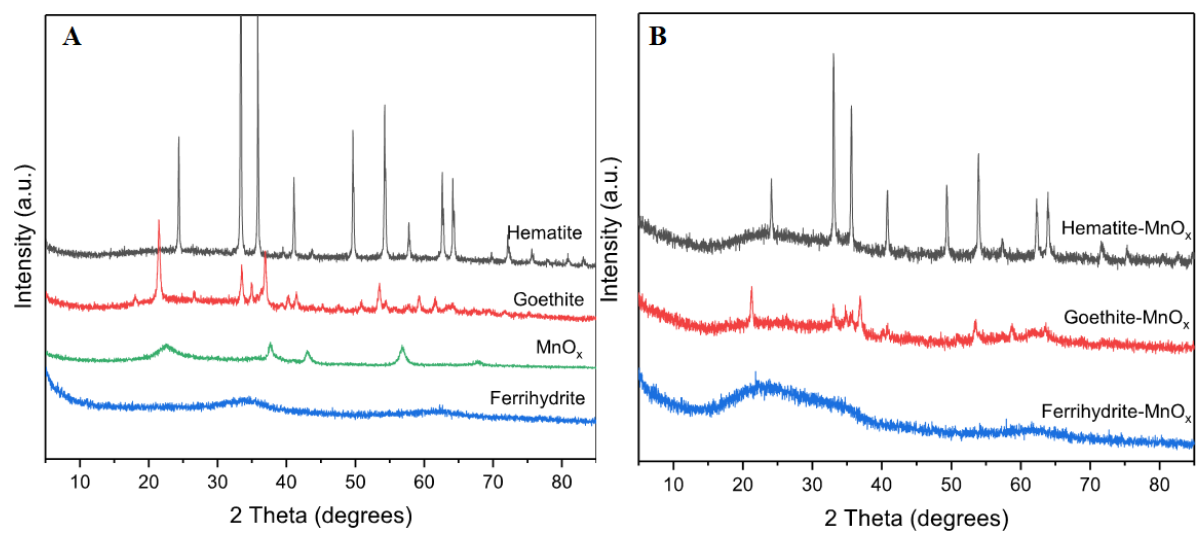

593 Figure S2. The XRD patterns of iron oxides and manganese oxide (A) and the corresponding Fe-Mn

binary oxides (B).

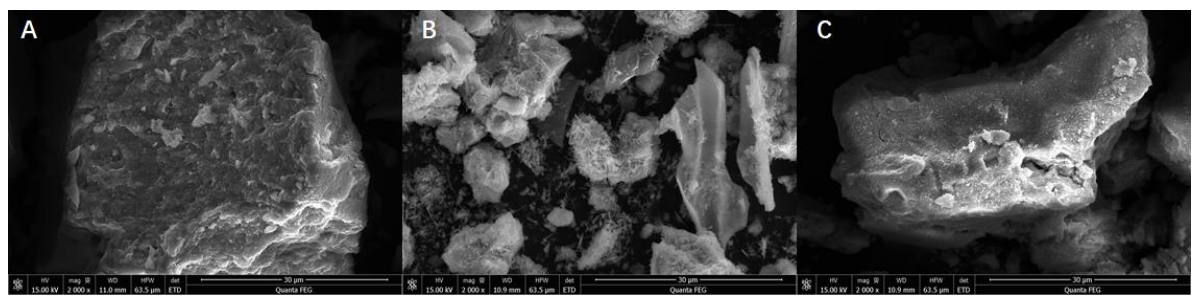

596 Figure S3. SEM morphology of ferrihydrite- (A), goethite-(B), and hematite-(C) containing Fe-Mn

597 binary oxides. 


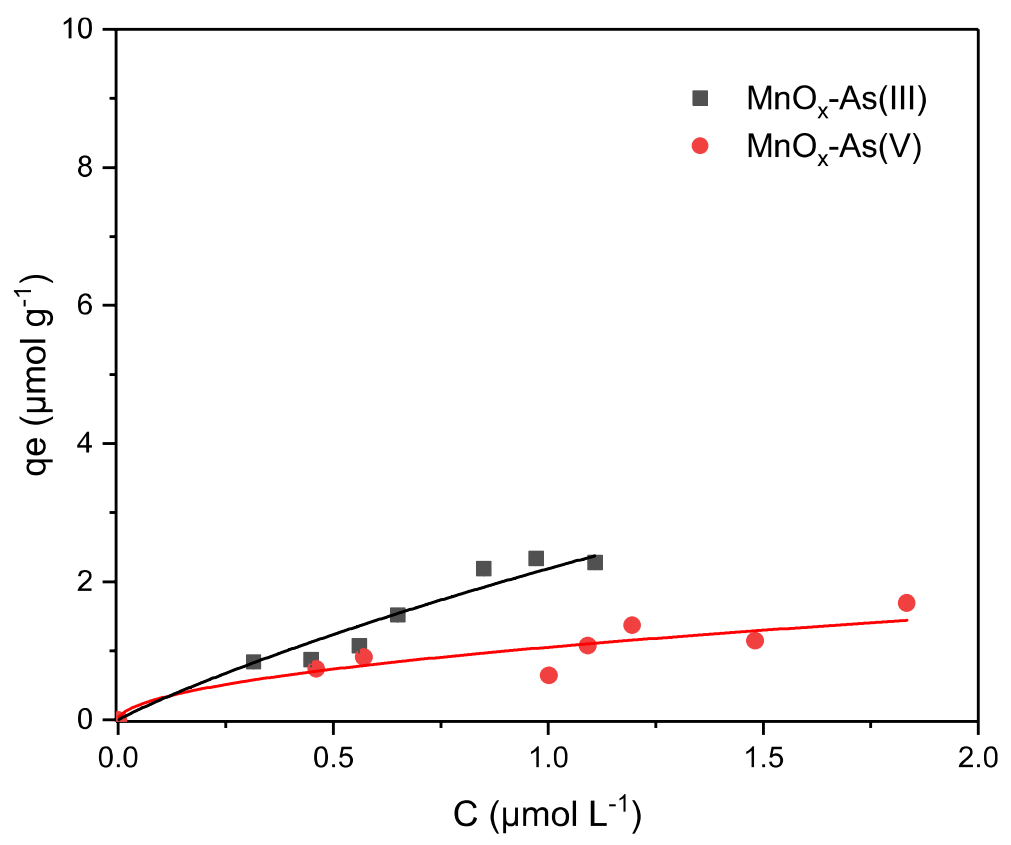

599 Figure S4. Adsorption isotherms for As(III) and As(V) by manganese oxide with a $100 \mathrm{mg} \mathrm{L}^{-1}$ suspension 600 at $\mathrm{pH} 7.0$.

601

602

603

604

605 606
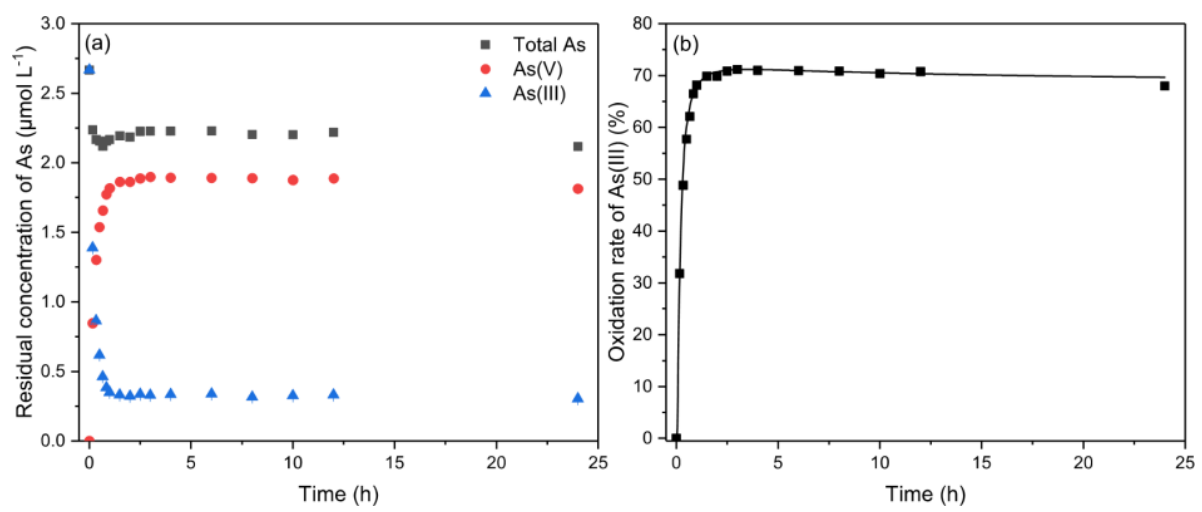

Figure S5. Evolution of the aqueous concentration of arsenic species (a) and the As(III) oxidation rate (b) with reaction time at $\mathrm{pH} 7.0$. Initial As(III) concentration was $2.67 \mu \mathrm{mol} \mathrm{L}{ }^{-1}$; Manganese oxide dosage was $100 \mathrm{mg} \mathrm{L}^{-1}$. 

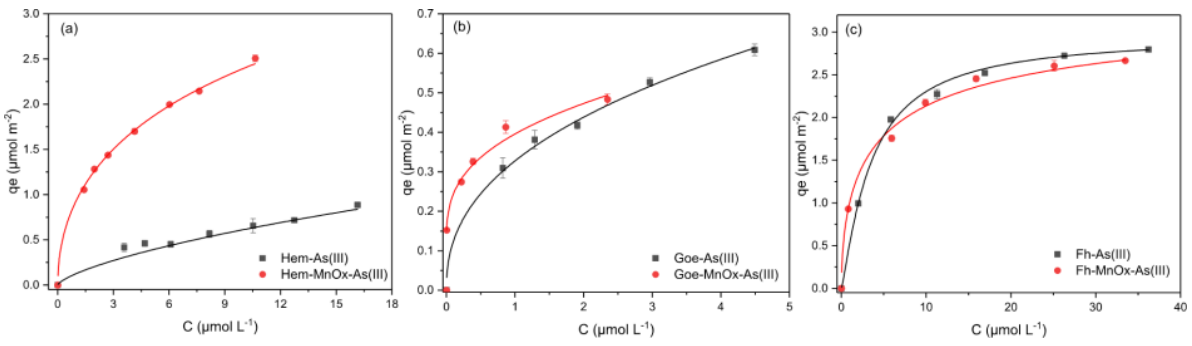

Figure S6. Adsorption isotherms for As(III) by different Fe-Mn binary oxides with a $0.2 \mathrm{mg} \mathrm{L}^{-1}$ dosage

at $\mathrm{pH}$ 7.0. All the data were normalized by specific surface areas.
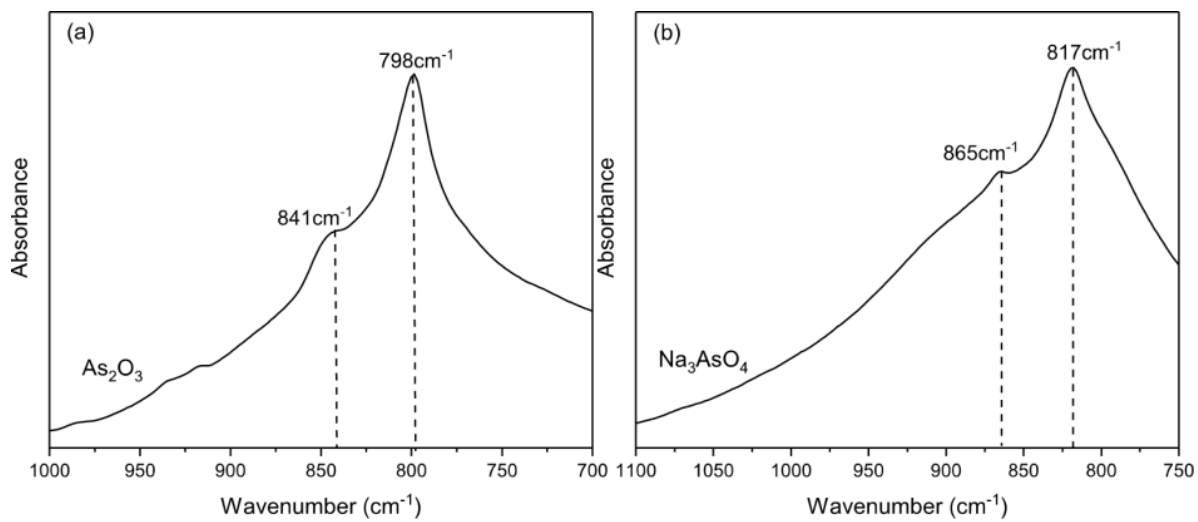

Figure S7. FTIR spectra of As(III) (a) and As(V) (b) standards.
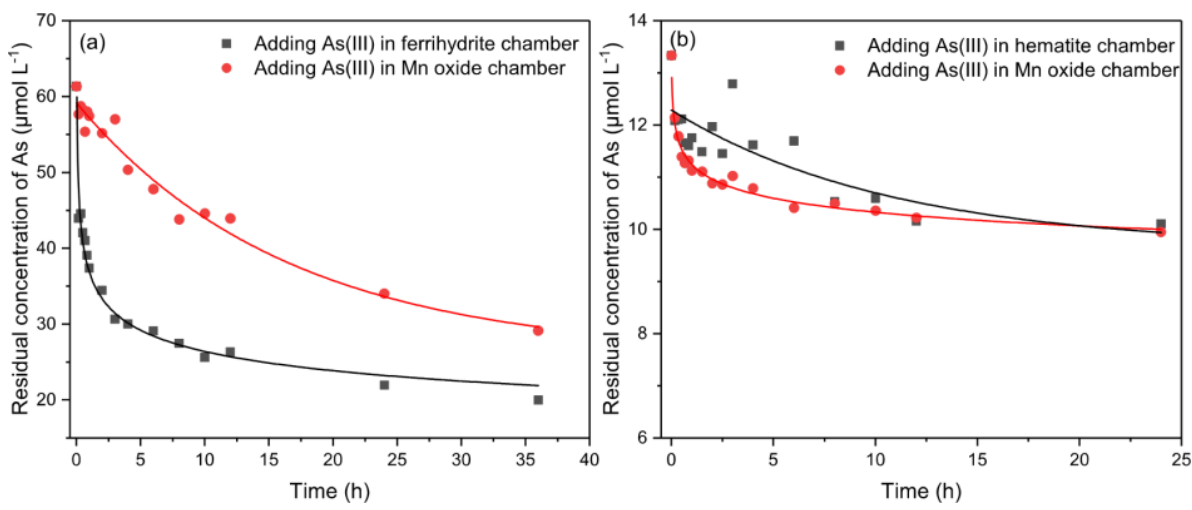

613 Figure S8. Evolution of aqueous arsenic concentration as a function of time in ferrihydrite-Mn oxide

(a) and hematite-Mn oxide (b) systems after adding As(III) into Fe or Mn oxides chambers. 

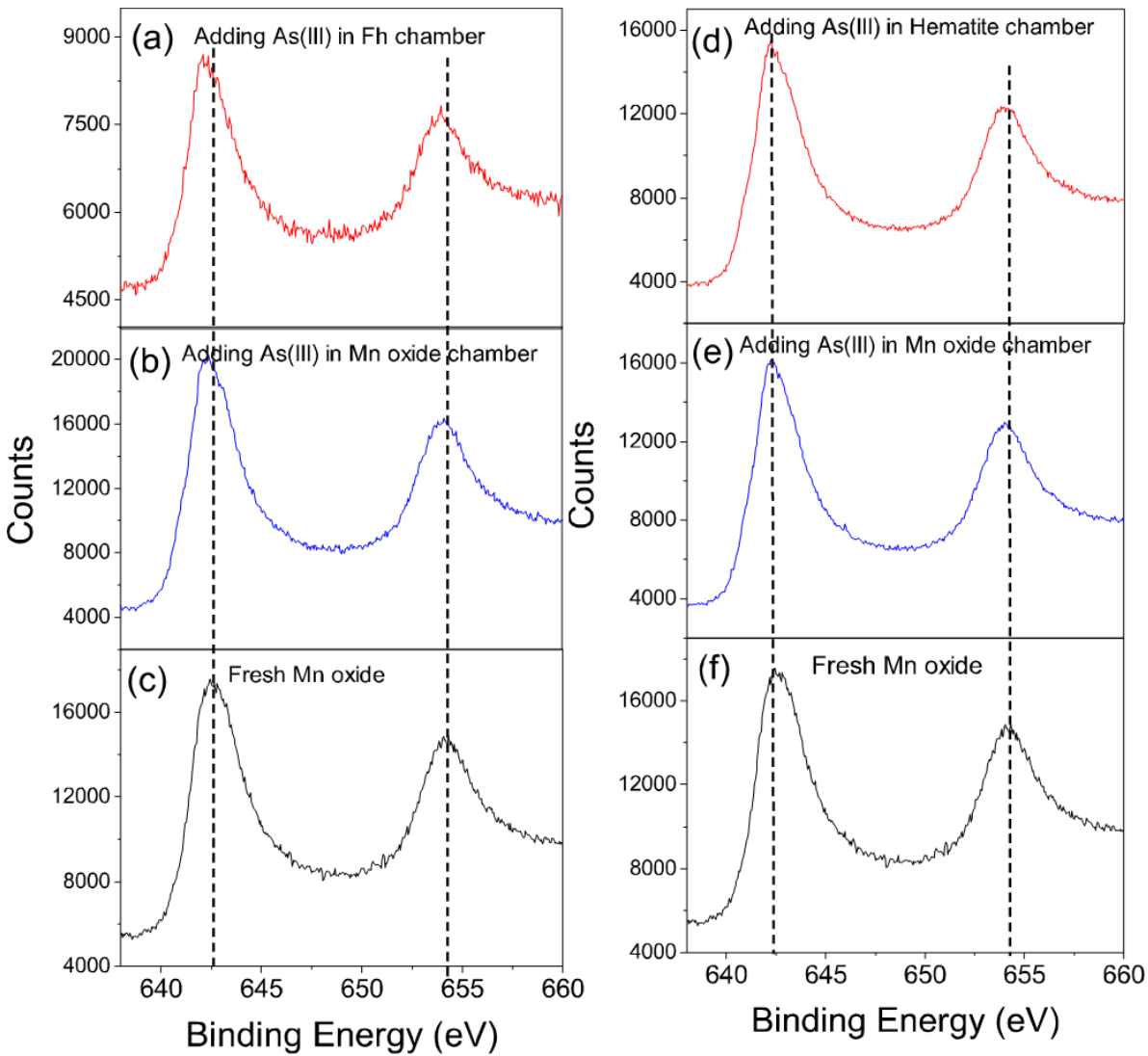

Figure S9. Mn2p XPS spectra of the Mn oxides in ferrihydrite-Mn oxide (a, b, c) and hematite-Mn oxide (d, e, f) systems before and after adding As(III) in Fe or Mn oxide chambers. 